\title{
Determination of Energy Balance and Economic Analysis of Cucumber (Cucumis Sativus) Production in Tillage Methods
}

Sanusi Bashri Adisa ${ }^{1}$, Ibrahim Saula Olarenwaju ${ }^{1}$, Jekayinfa Simeon Olatayo ${ }^{2}$, Akande Fatai Bukola ${ }^{2}$ and Ola Folorunso Adegboyega ${ }^{2 *}$

1. Department of Agricultural and Bio-Environmental Engineering, The Oke-Ogun Polytechnic, Saki, Oyo State, Nigeria

2. Department of Agricultural Engineering, Ladoke Akintola University of Technology, Ogbomoso, Oyo State, Nigeria

*Corresponding Author.faola@lauteh.edu.ng

\begin{abstract}
Energy whatever might be its source viz. human, animal, machine, electricity, solar, seed, chemical, fertilizer, gasoline or diesel has become a crucial input of agriculture right from preparatory tillage to the disposal of farm produce, energy input is necessary. This study investigates the energy balance and economic analysis of cucumber production in tillage methods. A tin of $50 \mathrm{~g}$ of treated cucumber seeds was planted in three different tillage systems namely; reduced, minimum and maximum tillage using foot dibbling method. Human power, machinery, diesel fuel, fertilizer, seed and pesticides were various forms of energy inputs used during the field cultivation of cucumber in the selected tillage methods. Input and output method of energy analysis was used to analyze the amount of input and output energies in each of the three tillage systems used in the production of cucumber. The calculated energy indices determined are energy ratio, energy productivity, specific energy, net energy and energy efficiency index. The result revealed that the highest total energy input and output values of 8694.09 and 8359.33 $\mathrm{MJha}^{-1}$ were estimated in maximum tillage, minimum tillage has an average values of 7774.42 and $12015 \mathrm{MJha}^{-1}$, while the least average values of 5688.26 and $12736.67 \mathrm{MJha}^{-1}$ were estimated in reduced tillage, respectively. The highest benefit-cost ratio of 2.94 was found in minimum tillage, followed by maximum tillage with a value of 2.35 , while least value of 2.08 was estimated in reduced tillage.
\end{abstract}

Keywords: Cucumber, tillage, energy, energy indices and net profit

DOI: $10.7176 / \mathrm{JETP} / 10-1-08$

Publication date: February $28^{\text {th }} 2020$

\section{Introduction}

Agriculture is both a producer and consumer of energy. It consumes large quantities of locally available noncommercial energy, such as seed, manure and animate energy, as well as commercial energy sources, directly and indirectly, in the form of diesel, electricity, fertilizer, plant protection chemical, irrigation water, machinery etc (Morteza et al., 2012). Energy use in agriculture has been increasing in response to increasing population, limited supply of arable land and a desire for higher standards of living (Kizilaslan, 2009). The increased use of inputs such as fertilizer, irrigation water, diesel, plant protection chemicals, electricity etc. demands more energy in the form of human, animal and machinery (Yadav and Khandelwal, 2013). Efficient use of these energies helps to achieve increased productivity and contributes to the economy, profitability and competitiveness of agricultural sustainability of rural communities (Omid et al., 2011). Improving energy use efficiency is becoming increasingly important for combating rising energy costs, depletion of natural resources and environmental deterioration (Ashkan et al., 2014).

Despite the fact that Nigeria is classified among the regions of traditional agriculture and where there is a high cost for acquiring farm machinery and equipment (Abdussalaam, 2015), many farmers still prefer replacing the conventional methods of land preparation with the use of tractor during land preparation for the production of crops. From the foregoing there are possibilities of replacement of popular conventional tillage with alternative tillage practices such as minimum and maximum tillage. The use of inappropriate tillage techniques has been found to be responsible for increased soil erosion, loss of fertility of agricultural soils, increased environmental hazards and has also contributes to unsustainability of crop production systems, as mechanized tillage requires high amount of energy input for an equal output per unit of cultivated area (Bertocco et al., 2008; Yildiz, 2016). Researchers such as Ashraf (2021), Tabatabaeefar et al. (2008) and Ashkan et al. (2014) investigates the effects of different tillage systems on energy consumption in the production of different crops and all of them reported that tillage is one of the major determinant factors which dictate the quantity of energy consumed during crop production. Therefore, there is need to study the energy balance and economic analyses of cucumber production in tillage methods with a view of selecting the most appropriate tillage method that will minimize the energy input and enhance the profitability of cucumber production. 


\section{Materials and Methods}

\section{$2.1 \quad$ Description of the study area}

The study was carried out at the seed unit of the Oyo State Agricultural Development Programme (OYSADEP), Saki, Saki West Local Government Council Area of Oyo North Senatorial District, Oyo State, Nigeria during raining season farming from April 2018 to July, 2020. Saki is within $8^{\circ} 40^{\prime} 3.43 \mathrm{~N}$ latitude and $3^{\circ} 23^{\prime} 38.15^{\circ}$ 'E longitude with an annual rainfall of about $900-1000 \mathrm{~mm}$ in the wet days, average of $72.7 \%$ relative humidity and temperature range of $21.8^{\circ} \mathrm{C}$ to $31.2^{\circ} \mathrm{C}$ (OYSADEP Annual Report, 2015). The community hosts a number of commercial and small farms, majorly specialized in the cultivation of food crops such as maize, guinea corn, cassava, yam, melon, cucumber to mention a few. The vegetation within the study area can be described as typical guinea savannah vegetation zone with favourable rainfall and adequate soils.

\subsection{Land preparation and experimental layout}

Preparation of experimental farm was carried out using manual method for reduced tillage treatment and tractor for both minimum and maximum tillage methods. The experimental farm was divided into three blocks and each block consists of three plots making a total of 9 experimental plots. The experimental farm was dimensioned $46 \mathrm{~m}$ x $46 \mathrm{~m}$, while each block was measured $46 \mathrm{~m}$ x $10 \mathrm{~m}$ and each plot with a dimension of $10 \mathrm{~m} \times 10 \mathrm{~m}$ with a space of $4 \mathrm{~m}$ in between the two adjacent plots which enabled the tractor to turn conveniently without entering the reduced tillage plots. The experimental farm was arranged in a complete randomized block design with each tillage method representing a treatment.

\subsection{Source of planting material}

A tin of $50 \mathrm{~g}$ of treated cucumber seeds was obtained from an agro vet shop at Ago-Aare in Atisbo Local Government Area of Oyo State, Nigeria and planted in three different tillage methods namely; reduced, minimum and maximum tillage using foot dibbling method as described by Abdussalaam (2015). Two to three seeds of cucumber were directly placed into the soil made with foot, slightly covered with soil and foot pressed.

\section{$2.4 \quad$ Energy analysis}

Identification of required operations, choosing the appropriate machinery and the right method of operation are important factors for effective analysis of energy used during the production of different crops. Operational (direct) energy consumption for the production of the cucumber, such as in land preparation, planting, fertilizer application, weeding, plant protection and harvesting were determined using input and output method of energy analysis. For converting farm inputs and outputs to energy, different energy conversion coefficients were used and these were extracted from Ashkan (2014), Fadavi et al. (2011), Abdussalam (2015) and Isaac and Babajide (2015). Major energy inputs that were utilized during tillage and other farming operations during field cultivation of cucumber include human energy, machinery, diesel fuel, fertilizer, seed and pesticides. The identified farming operations and equipment used in the three tillage methods are presented in Table 1.

Table 1. Farming operations and equipment used in the production of cucumber

\begin{tabular}{|c|c|c|c|c|}
\hline $\mathbf{S} / \mathbf{N}$ & Operations & \multicolumn{3}{|c|}{ Principle Adopted and Equipment Used } \\
\hline & & Reduced & Minimum & Maximum \\
\hline 1 & Land preparation & $\begin{array}{l}\text { Manual with the use } \\
\text { of hoe and cutlass }\end{array}$ & $\begin{array}{l}\text { Mechanized, } \\
\text { tractor, plough }\end{array}$ & $\begin{array}{l}\text { Mechanized, 4W tractor, } \\
\text { plough and harrow }\end{array}$ \\
\hline 2 & Planting & $\begin{array}{l}\text { Manual and } \\
\text { knapsack sprayer }\end{array}$ & $\begin{array}{l}\text { Manual and knapsack } \\
\text { sprayer }\end{array}$ & $\begin{array}{l}\text { Manual and knapsack } \\
\text { sprayer }\end{array}$ \\
\hline 3 & Weeding & $\begin{array}{l}\text { Manual and } \\
\text { knapsack sprayer }\end{array}$ & $\begin{array}{l}\text { Manual and knapsack } \\
\text { sprayer }\end{array}$ & $\begin{array}{l}\text { Manual and knapsack } \\
\text { sprayer }\end{array}$ \\
\hline 4 & $\begin{array}{l}\text { Fertilizer } \\
\text { application }\end{array}$ & $\begin{array}{l}\text { Manual with the use } \\
\text { of knapsack sprayer }\end{array}$ & $\begin{array}{l}\text { Manual with the use of } \\
\text { knapsack sprayer }\end{array}$ & $\begin{array}{l}\text { Manual with the use of } \\
\text { knapsack sprayer }\end{array}$ \\
\hline 5 & Plant protection & $\begin{array}{l}\text { Manual with the use } \\
\text { of knapsack sprayer }\end{array}$ & $\begin{array}{l}\text { Manual with the use of } \\
\text { knapsack sprayer }\end{array}$ & $\begin{array}{l}\text { Manual with the use of } \\
\text { knapsack sprayer }\end{array}$ \\
\hline 6 & Harvesting & $\begin{array}{l}\text { Manual by hand } \\
\text { picking }\end{array}$ & Manual by hand picking & Manual by hand picking \\
\hline
\end{tabular}


2.4.1 Energy demand of land preparation in tillage methods

Energy demands of land preparation in reduced tillage using human power and for both minimum and maximum tillage using tractorization method are obtained by using equations 1and 2, respectively as described by Isaac and Babajide (2015) as:

$$
\begin{array}{ll}
E_{l p}=3.6(0.075 N T a) & 1 \\
E_{l p}=47.8 D+3.6(0.075 N T a) & 2
\end{array}
$$

Where:- $D=$ Amount of diesel consumed per unit operation (L), $T a=$ Useful time spent by a male worker per unit operation (hr), $N=$ Number of persons involved in an operation

2.4.2 Planting, fertilizer application, weeding and plant protection operations

The energy demands of planting, fertilizer, weeding and plant protection operations was estimated from the addition of the equivalent energy of the physical inputs used per hectare from cucumber seed, fertilizer, pesticide and human energy expended during field planting of cucumber. The total energy consumed during planting was expressed from equations 3 and 4 as described by Ashkan (2014) and Isaac and Babajide (2015):

$$
\begin{array}{ll}
E_{S}=\text { Quantity used }\left(\frac{\mathrm{kg}}{\mathrm{ha}}\right) \text { x energy equivalent } & 3 \\
E_{M}=3.6(0.075 \mathrm{NTa}) & 4
\end{array}
$$

Therefore, embodied energy demand for planting operation was expressed by equation 5 as:

$$
E_{P=E_{S}}+E_{M}
$$

Where: $-E_{S}=$ Seed energy input $(\mathrm{Kg} / \mathrm{ha}), E_{M}=$ Human energy $(\mathrm{MJ} / \mathrm{ha})$

It should be noted that weeding operation was carried out using both hoeing and chemical control methods.

\subsubsection{Energy demand of cucumber harvest}

Harvesting of cucumber fruits was done manually by picking the matured fruits with bare hand. The time taken by the workers to harvest the fruits, the number of people involved and the quantity of fruits harvested were recorded. Energy demand of harvesting operation was analyzed using the expression in equation 6 as described by Isaac and Babajide (2015):

$$
E_{M}=3.6(0.075 \mathrm{NTa})
$$

\subsubsection{Energy indices of cucumber production}

The calculated energy indices of cucumber production in tillage methods in terms of energy ratio (ER), Energy Productivity (EP), Specific Energy (SE), Net Energy (NE) and Energy efficiency index (EEN) were calculated using equations 7, 8, 9 and 10, respectively as described by Abdussalam (2015) as:

$$
\begin{aligned}
& \text { Energy Ratio }=\frac{\text { Energy output }\left(M J h a^{-1}\right)}{\text { Energy input }\left(M J h a^{-1}\right)} \\
& \text { Energy Productivity }=\frac{\text { Crop Yield }\left(\mathrm{kgha}^{-1}\right)}{\text { Total Energy input }\left(M J h a^{-1}\right)} \\
& \text { Specific Energy }=\frac{\text { Energy input }\left(M J h a^{-1}\right)}{\text { Crop output }\left(M J h a^{-1}\right)} \\
& \text { Net Energy }=\frac{\text { Energy output }\left(M J h a^{-1}\right)}{\text { Energy input }\left(M J h a^{-1}\right)} \\
& \text { Energy Efficiency Index }=\frac{E_{0}-E_{i}}{E_{0}} \times 100
\end{aligned}
$$

Where:- $E i=$ Energy input $(\mathrm{MJ} / \mathrm{ha}), E o=$ Energy output $(\mathrm{MJ} / \mathrm{ha})$

The different forms of energy inputs used in the analysis of the cucumber production and their energy equivalent and are as presented in Table 2. 
Table 2: Energy equivalents of input and output in agricultural productions

\begin{tabular}{llll}
\hline Input Source & Unit & Energy equivalent (MJ) & References \\
\hline Human labour & $\mathrm{H}$ & 1.96 & Ashkan et al., 2014 \\
Machinery & $\mathrm{H}$ & 69.83 & Morteza et al., 2012 \\
Diesel fuel & $\mathrm{L}$ & 56.31 & Morteza et al., 2012 \\
\hline Chemical Fertilizers & & & \\
\hline Nitrogen & $\mathrm{Kg}$ & 78.1 & Fadavi et al., 2011 \\
Phosphorus & $\mathrm{Kg}$ & 15.80 & Yildiz, 2016 \\
Potassium (kg) & & 9.28 & Erdal et al., 2007 \\
Cucumber seed & $\mathrm{Kg}$ & 0.7 & Morteza et al., 2012 \\
\hline
\end{tabular}

2.5 Economic analysis and cost benefit ratio of cucumber production

The economic analysis of cucumber production in terms of total cost of production, gross and net monetary returns was analyzed using the method described by Khan et al. (2009).

\subsubsection{Total cost of production}

The total cost of production (cost C) of cucumber production was estimated by using the addition of monetary values of all energy inputs during different tillage and farming operations such as labourer, fertilizer, chemical, seed, fuel, hired machinery and tractor with implement for farming operations.

\subsubsection{Gross monetary returns}

Gross monetary return was estimated by multiplying the energy outputs (yields) of the crop by the market price in naira per $\mathrm{kg}\left(\mathrm{kg}^{-1}\right)$ using equation 12 as described by Khan et al. (2009):

$$
\text { Gross monetary Return }=\text { Yield }\left(\mathrm{kgha}^{-1}\right) \times \text { Market price of the yield }\left(\mathrm{Ng}^{-1}\right)
$$

\subsubsection{Net monetary returns}

The net economic return of cucumber production was calculated as gross return minus the total cost of production (Khan et al., 2009) by equation 13:

$$
\text { Net monetary return }=\text { Gross monetary return }\left(\mathrm{Nha}^{-1}\right)-\text { Total production cost }\left(\mathrm{Nha}^{-1}\right)
$$

\subsubsection{Cost benefit ratio}

The cost benefit ratio was calculated using the expression described by Majid (2011) in equation 14 as:

$$
\text { Cost benefit ratio }=\frac{\text { Gross monetary return }}{\text { Total cost of production }}
$$

\section{Results and Discussions}

\subsection{Analysis of input-output energy use in cucumber production in tillage methods}

The physical inputs used in cucumber production and their energy equivalents together with the energy equivalent of the yield are shown in Table 3. It is observed from the table that reduced tillage has the highest physical human power input which varied from $330.44-350.0 \mathrm{~h}$ with an average of $333.48 \mathrm{~h}$, followed by maximum tillage with a range of $149.0-189.0 \mathrm{~h}$ and an average value of $148.4 \mathrm{~h}$, while the least human power input ranges from 114.13 $-175.0 \mathrm{~h}$ with an average of $144.56 \mathrm{~h}$ was used in minimum tillage. The highest machinery physical input was recorded in maximum tillage which varied from $14.64-16.5 \mathrm{~h}$ with an average value of $15.30 \mathrm{~h}$, minimum tillage has a range of $11.4-11.6 \mathrm{~h}$ with average value of $11.2 \mathrm{~h}$, while the least machinery input range of $5.8-6.5 \mathrm{~h}$ with an average of $5.9 \mathrm{~h}$ was observed in reduced tillage. The same amount of fertilizer, seed and pesticide inputs of $29.42 \mathrm{~kg}, 6.4 \mathrm{~kg}$ and 6.25 liters, respectively were used on yearly basis for the production of cucumber for the three tillage methods treated. The highest total energy input between the ranges of 8196.54 and $9525.61 \mathrm{MJha}^{-1}$ was estimated in maximum tillage, minimum tillage has a range of 7474.37 and $8297.54 \mathrm{MJha}^{-1}$, while the least range of 5677.65 and $5764.87 \mathrm{MJha}^{-1}$ of total energy was estimated in reduced tillage for the three cropping seasons. Morteza et al., (2012) reported similar result with total human hourly input of $45.98 \mathrm{hha}^{-1}, 18.85 \mathrm{hha}^{-1}$ of machinery input and total energy input of 39,232.79 $\mathrm{MJha}^{-1}$ in the production of corn grain, while Ashraf et al. (2021) reported labor input, machinery input, total Energy input respectively of $59.50 \mathrm{hha}^{-1}, 26.25 \mathrm{hha}^{-1}, 21360.0 \mathrm{MJha}^{-1}$ and $242.70 \mathrm{hha}^{-1}, 80.05 \mathrm{hha}^{-1}, 44370.0 \mathrm{MJha}^{-1}$ for wheat and rice productions respectively.

The highest cucumber yield range of 12345 and $12990 \mathrm{kgha}^{-1}$ with an average yield value of $12736.7 \mathrm{kgha}^{-1} \mathrm{was}$ harvested in maximum tillage plots, followed by minimum tillage which ranges between 12120 and $12670 \mathrm{kgha}^{-1}$ with an average yield of $12415.33 \mathrm{kgha}^{-1}$, while the least harvested yield range of 8620 and $9760 \mathrm{kgha}^{-1} \mathrm{was}^{-1}$ harvested in reduced tillage. This result is similar to the findings of Morteza et al. (2012) who reported an average 
yield of $12250 \mathrm{kgha}^{-1}$ and total energy output of $96359.10 \mathrm{MJha}^{-1}$ for corn grain production. Similarly grain yield and energy output of $4325.38 \mathrm{kgha}^{-1}$ and $121500.0 \mathrm{MJha}^{-1}$ in wheat and $4441.24 \mathrm{kgha}^{-1}$ and $75500 \mathrm{MJha}^{-1}$ in rice productions, respectively were reported by Ashraf et al. (2021).

The anthropogenic energy input ratios of cucumber production in the three tillage methods, namely; reduced, minimum and maximum is presented in Figure 1. It is noticed from the figure that the highest average human energy input of $653.62 \mathrm{MJha}^{-1}$ was used in reduced tillage, followed by maximum tillage with a value of 333.98 $\mathrm{MJha}^{-1}$, while the least human energy input of $290.82 \mathrm{MJha}^{-1}$ was recorded in minimum tillage. Maximum tillage has the highest average machinery energy input of $1069.10 \mathrm{MJha}^{-1}$, followed by minimum tillage with an average value of $782.10 \mathrm{MJha}^{-1}$, while the least average machinery input of $409.90 \mathrm{MJha}^{-1}$ was obtained in reduced tillage. The highest diesel fuel energy input with an average value of $2664.68 \mathrm{MJha}^{-1}$ was estimated in maximum tillage, followed by minimum tillage with an average value of $2076.34 \mathrm{MJha}^{-1}$, while zero value of diesel fuel energy input was consumed in reduced tillage. Figure 1 further revealed that the same quantity of fertilizer, seed and pesticides inputs with average values of $2123.54,7.60$ and $24945 \mathrm{MJha}^{-1}$, respectively were used on yearly basis in the three tillage methods.

TABLE 3: Physical energy input used in the production of cucumber

\begin{tabular}{|c|c|c|c|c|c|c|c|}
\hline \multirow{2}{*}{$\begin{array}{l}\text { Item } \\
2018 \\
\end{array}$} & \multicolumn{3}{|c|}{$\begin{array}{l}\text { Quantity used in Tillage Methods } \\
\text { (ha) }\end{array}$} & \multirow[t]{2}{*}{$\begin{array}{l}\text { Energy } \\
\text { Equiv. }\end{array}$} & \multicolumn{3}{|c|}{ Total Energy Equivalent (MJ/ha) } \\
\hline & Reduced & Minimum & Maximum & & Reduced & Minimum & Maximum \\
\hline Human power, $\mathrm{h}$ & 350 & 175 & 189 & 1.96 & 686 & 343 & 370.44 \\
\hline Machinery, h & 6.5 & 11.4 & 16.5 & 69.83 & 453.90 & 796.06 & 1152.20 \\
\hline Diesel Fuel, L & 00 & 45 & 60 & 56.3 & 00 & 2533.5 & 3378 \\
\hline Fertilizer, kg & 29.42 & 29.42 & 29.42 & 72.18 & 2123.37 & 2123.37 & 2123.37 \\
\hline Seed, $\mathrm{kg}$ & 6.4 & 6.4 & 6.4 & 1.70 & 7.60 & 7.60 & 7.60 \\
\hline Pesticide, L & 7.35 & 7.35 & 7.35 & 339.20 & 2494 & 2494 & 2494 \\
\hline $\begin{array}{l}\text { Total energy input } \\
(\mathrm{MJ} / \mathrm{ha})\end{array}$ & & & & & 5764.87 & 8297.54 & 9525.61 \\
\hline Yield (kg/ha) & & & & & 9760 & 12670 & 12990 \\
\hline $\begin{array}{l}\text { Total energy output } \\
(\mathrm{MJ} / \mathrm{ha})\end{array}$ & & & & & 7808 & 10136 & 10392 \\
\hline 2019 & Reduced & Minimum & Maximum & & Reduced & Minimum & Maximum \\
\hline Human power, $\mathrm{h}$ & 320 & 156 & 173.01 & 1.96 & 627.20 & 305.76 & 339.09 \\
\hline Machinery, h & 5.3 & 10.6 & 14.78 & 69.83 & 370.10 & 740.20 & 1032.09 \\
\hline Diesel Fuel, L & 00 & 33.40 & 42 & 56.3 & 00 & 1880.42 & 2364.6 \\
\hline Fertilizer, kg & 29.42 & 29.42 & 29.42 & 72.18 & 2123.37 & 2123.37 & 2123.37 \\
\hline Seed, $\mathrm{kg}$ & 6.4 & 6.4 & 6.4 & 1.70 & 7.60 & 7.60 & 7.60 \\
\hline Pesticide, L & 7.35 & 7.35 & 7.35 & 339.20 & 2494 & 2494 & 2494 \\
\hline $\begin{array}{l}\text { Total energy input } \\
(\mathrm{MJ} / \mathrm{ha})\end{array}$ & & & & & 5622.27 & 7594.35 & 8360.75 \\
\hline Yield $(\mathrm{kg} / \mathrm{ha})$ & & & & & 8650 & 12120 & 12345 \\
\hline $\begin{array}{l}\text { Total energy output } \\
(\mathrm{MJ} / \mathrm{ha})\end{array}$ & & & & & 6920 & 9696 & 9876 \\
\hline 2020 & Reduced & Minimum & Maximum & & Reduced & Minimum & Maximum \\
\hline Human power, $\mathrm{h}$ & 330.44 & 114.13 & 149.18 & 1.96 & 647.67 & 223.69 & 292.40 \\
\hline Machinery, $\mathrm{h}$ & 5.8 & 11.6 & 14.64 & 69.83 & 405.01 & 810.03 & 1022.10 \\
\hline Diesel Fuel, L & 00 & 32.25 & 40 & 56.3 & 00 & 1815.68 & 2257.07 \\
\hline Fertilizer, kg & 29.42 & 29.42 & 29.42 & 72.18 & 2123.37 & 2123.37 & 2123.37 \\
\hline Seed, $\mathrm{kg}$ & 6.4 & 6.4 & 6.4 & 1.70 & 7.60 & 7.60 & 7.60 \\
\hline Pesticide, L & 7.35 & 7.35 & 7.35 & 339.20 & 2494 & 2494 & 2494 \\
\hline $\begin{array}{l}\text { Total energy input } \\
(\mathrm{MJ} / \mathrm{ha})\end{array}$ & & & & & 5677.65 & 7474.37 & 8196.54 \\
\hline Yield (kg/ha) & & & & & 8620 & 12456 & 12875 \\
\hline $\begin{array}{l}\text { Total energy output } \\
(\mathrm{MJ} / \mathrm{ha})\end{array}$ & & & & & 6898 & 9964 & 10300 \\
\hline
\end{tabular}




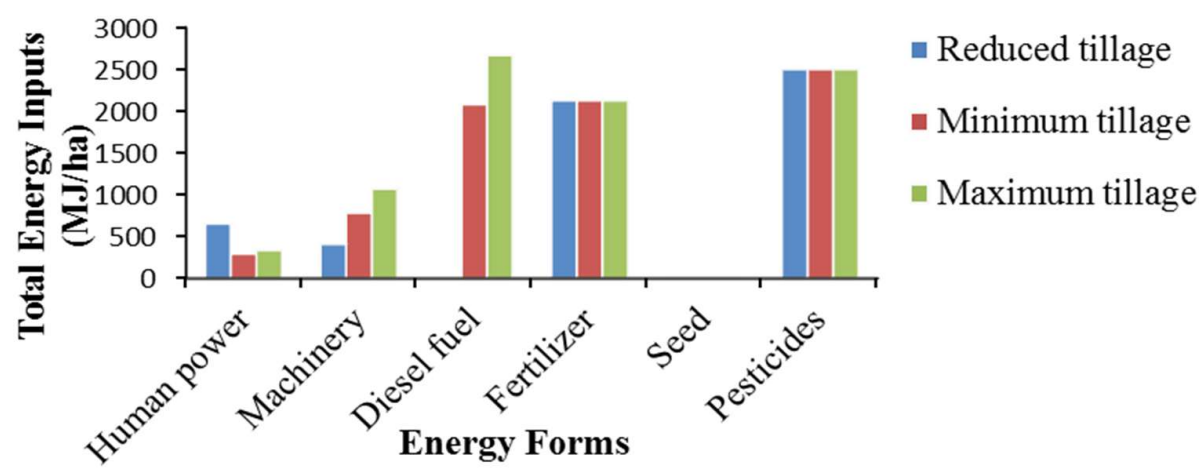

Figure 1: Anthropogenic energy input ratios of cucumber production in tillage methods

The percentage of total energy consumptions by operations in tillage methods are presented in Figures 2, 3 and 4 . It can be seen from Figure 2 that for reduced tillage, plant protection has the highest percentage of energy expenditure with $45 \%$, followed by fertilizer application with a value of $35 \%$, land preparation has a percentage value of $15 \%$, planting has a share of $2 \%$ of total energy expended, while the lowest percentage value of $1 \%$ was recorded for weeding and staking operations.

Similarly, Figure 3 presents the percentage composition of energy consumed by the operations in minimum tillage during the production of cucumber and it is revealed from the figure that the highest percentage energy composition value of $37 \%$ was recorded during land preparation, crop protection has a percentage value of $34 \%$, fertilizer application accounted for $25 \%$ of total energy consumed, while planting, weeding, staking and harvesting recorded the least equal percentage energy value of $1 \%$.

The percentage composition of energy consumed by operations during the production of cucumber in maximum tillage is presented in Figure 4. It can be seen from the figure that the highest percentage energy value of $43 \%$ was recorded during land preparation, followed by plant protection with percentage energy value of $30 \%$, fertilizer application has a percentage value of $23 \%$, while the least energy percentage composition of $1 \%$ was calculated for planting, weeding, staking and harvesting operations. This result is similar to the findings of Abdussalam (2015) who reported energy consumption composition of $58 \%$ for land preparation, $36 \%$ for ridging, $3 \%$ for weeding operation, $2 \%$ for application of fertilizer and $1 \%$ for planting in the production of maize. Ashraf et al., 2021 reported energy inputs composition of $28.96 \%$ for chemical fertilizers, $6.31 \%$ for rice seed energy, $44.61 \%$ of diesel fuel energy, $10.14 \%$ for electricity, $1.85 \%$ for machinery, $5.32 \%$ for pesticides energy and $2.82 \%$ for human labour energy respectively.

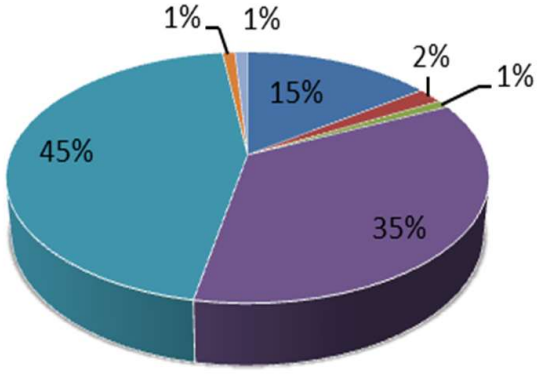

- Land preparation

- Planting

- Weeding

- Fertilizer application

- Plant protection

- Staking

- Harvesting

Figure 2: Composition of Energy Consumed by Operations in Reduced Tillage 


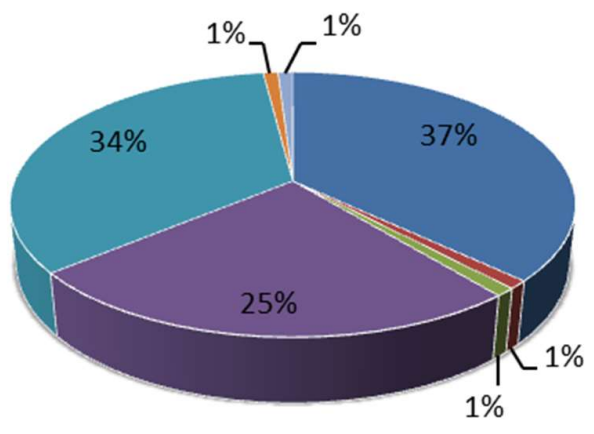

- Land preparation

- Planting

- Weeding

घ Fertilizer application

- Plant protection

- Staking

- Harvesting

Figure 3: Composition of Energy Consumed by Operations in Minimum Tillage

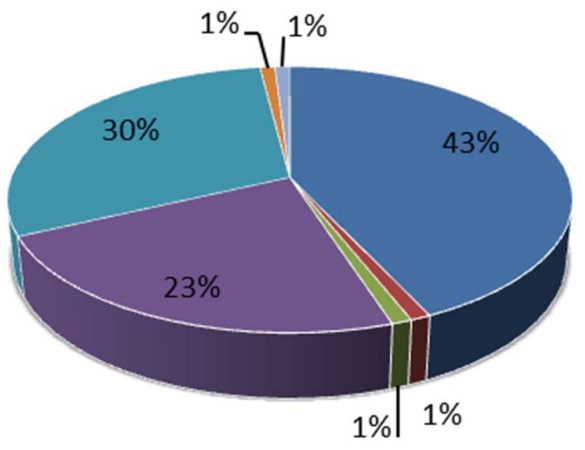

- Land preparation

- Planting

- Weeding

- Fertilizer application

- Plant protection

- Staking

- Harvesting

Figure 4: Composition of Energy Consumed by Operations in Maximum Tillage

\subsection{Energy indices in cucumber production in tillage methods}

The calculated energy ratio (energy use efficiency), energy productivity, specific energy, net energy gain and percentage energy index of cucumber production in the three tillage methods in the three cropping seasons is presented in Table 4. It can be seen from the table that minimum tillage has the highest energy ratio between the range of 1.22 and 1.67 with an average value of 1.39 , followed by maximum tillage between the range of 1.25 and 1.48 with an average of 1.27 , while the least energy ratio between the range of 1.21 and 1.35 with average value of 1.26 was calculated in reduced tillage. The highest energy productivity within the range of 1.53 and $1.67 \mathrm{MJkg}^{-}$ ${ }^{1}$ with an average of $1.6 \mathrm{MJkg}^{-1}$ was observed in minimum tillage, reduced tillage has a range of $1.52 \mathrm{MJkg}^{-1}$ and $1.69 \mathrm{MJkg}^{-1}$ with average value of $1.58 \mathrm{MJkg}^{-1}$, while maximum tillage has the lowest energy productivity range of 1.18 and $1.36 \mathrm{MJkg}^{-1}$ with an average of $1.47 \mathrm{MJkg}^{-1}$. Maximum tillage recorded the highest specific energy with a range of 0.64 and $0.73 \mathrm{MJha}^{-1}$ with average value of $0.68 \mathrm{MJha}^{-1}$, followed by reduced tillage between the range of 0.59 and $0.66 \mathrm{MJha}^{-1}$ with average of $0.63 \mathrm{MJha}^{-1}$, while the least specific energy between the values of 0.60 and $0.65 \mathrm{MJha}^{-1}$ with average of $0.62 \mathrm{MJha}^{-1}$ is observed in minimum tillage. The highest net energy gain between the ranges of 1838.46 and $2490.43 \mathrm{MJha}^{-1}$ with average value of $2157.84 \mathrm{MJha}^{-1}$ was estimated in minimum tillage, reduced tillage has a range of 1220.35 and $2043.13 \mathrm{MJha}^{-1}$ with an average value of 1520.40 $\mathrm{MJha}^{-1}$, while maximum tillage has the least energy gain between the range of 610.11 and $2103.46 \mathrm{MJ} / \mathrm{ha}$ with an average of $1409.60 \mathrm{MJha}^{-1}$. The highest percentage energy index between the range of 0.18 and $0.25 \%$ with an average value of $0.22 \%$ was estimated in minimum tillage, followed by reduced tillage with a range of 0.18 and $0.26 \%$ with an average of $0.21 \%$, while the least percentage energy index between a range of 0.06 and $0.20 \%$ with an average value of 0.14 was estimated in maximum tillage. Pishgar Komleh et al. (2011) in their studied reported energy efficiency, energy productivity, specific energy and net energy of $2.27,0.28 \mathrm{kgMJ}^{-1}, 3.76 \mathrm{MJ}^{-1}$ and $79452 \mathrm{MJ} \mathrm{ha}^{-1}$, respectively for corn silage production, while Morteza et al. (2012) reported corresponding values 2.6, $0.18 \mathrm{kgMJ}^{-1}, 5.66 \mathrm{MJkg}^{-1}$ and 59,248.58 $\mathrm{MJha}^{-1}$ for corn grain production

3.3 Economic analysis and cost benefit ratio in cucumber production

The calculated economic analysis in cucumber production in terms of total cost of production, gross and net monetary returns and cost benefit ration in three tillage methods is presented in Table 5. It is observed from the table that maximum tillage has the highest total cost of production with the sum of $\$ 276,000.00 \mathrm{k}$, followed by 
reduced tillage with a total sum of $\$ 234,750.00 \mathrm{k}$, while the least sum of $\$ 215,000.00 \mathrm{k}$ was estimated in minimum tillage. The highest gross monetary return with the sum of $\$ 649,500.00 \mathrm{k}$ was realized in maximum tillage, minimum tillage has a total sum of $\$ 633,500.00 \mathrm{k}$ and the least gross monetary return with a total sum of $\$ 488,000.00 \mathrm{k}$ was realized in reduced tillage.

The highest sum of $\$ 418,500.00 \mathrm{k}$ net monetary returns was calculated in reduced tillage, followed by maximum tillage with a sum of $\$ 373,500.00 \mathrm{k}$, while the least sum of $\$ 253,250.00 \mathrm{k}$ was realized in reduced tillage. Minimum tillage has the highest cost benefit ratio of 2.94, followed by maximum tillage with a value of 2.35 and the least value of 2.08 cost benefit value was observed in reduced tillage. This result is similar to the findings of Morteza et al. (2012) who reported cost benefit ratios of 1.75 for corn grain production, respectively.

Table 4: Energy indices in cucumber production in tillage methods

\begin{tabular}{|c|c|c|c|c|c|}
\hline \multirow[t]{2}{*}{ Year } & \multirow[t]{2}{*}{ Items } & \multirow[t]{2}{*}{ Units } & \multicolumn{3}{|c|}{ Quantity } \\
\hline & & & Reduced & Minimum & Maximum \\
\hline \multirow[t]{8}{*}{2018} & Total energy input & MJha $^{-1}$ & 5764.87 & 8297.54 & 9525.09 \\
\hline & Yield & $\mathrm{Kg} / \mathrm{ha}$ & 9760 & 12670 & 12990 \\
\hline & Total energy output & MJha $^{-1}$ & 7808.00 & 10136 & 10392 \\
\hline & Energy use efficiency & & 1.35 & 1.22 & 1.09 \\
\hline & Energy productivity & $\mathrm{MJkg}^{-1}$ & 1.69 & 1.53 & 1.36 \\
\hline & Specific energy & MJha $^{-1}$ & 0.59 & 0.65 & 0.73 \\
\hline & Net energy gain & MJha $^{-1}$ & 2043.13 & 1838.46 & 610.11 \\
\hline & $\%$ energy index & & 0.26 & 0.18 & 0.06 \\
\hline \multirow[t]{8}{*}{2019} & Total energy input & MJha $^{-1}$ & 5622.27 & 7551.35 & 8360.75 \\
\hline & Yield & $\mathrm{Kg} / \mathrm{ha}$ & 8650 & 12120 & 12345 \\
\hline & Total energy output & MJha $^{-1}$ & 6920.00 & 10832.00 & 11984.00 \\
\hline & Energy use efficiency & & 1.23 & 1.28 & 1.18 \\
\hline & Energy productivity & $\mathrm{MJkg}^{-1}$ & 1.54 & 1.60 & 1.48 \\
\hline & Specific energy & MJha $^{-1}$ & 0.65 & 0.62 & 0.68 \\
\hline & Net energy gain & MJha $^{-1}$ & 1297.73 & 2144.64 & 1515.25 \\
\hline & $\%$ energy index & & 0.19 & 0.22 & 0.15 \\
\hline \multirow[t]{8}{*}{2020} & Total energy input & MJha $^{-1}$ & 5677.65 & 7474.37 & 8196.54 \\
\hline & Yield & $\mathrm{kg} / \mathrm{ha}$ & 8620 & 12543 & 12875 \\
\hline & Total energy output & MJha $^{-1}$ & 6898 & 9964.8 & 10300 \\
\hline & Energy use efficiency & & 1.21 & 1.67 & 1.25 \\
\hline & Energy productivity & $\mathrm{MJkg}^{-1}$ & 1.52 & 1.67 & 1.57 \\
\hline & Specific energy & MJha $^{-1}$ & 0.66 & 0.60 & 0.64 \\
\hline & Net energy gain & MJha $^{-1}$ & 1220.35 & 2490.43 & 2103.46 \\
\hline & $\%$ energy index & & 0.18 & 0.25 & 0.20 \\
\hline
\end{tabular}

Table 5: Economic analysis and benefit-cost ratio of cucumber

\begin{tabular}{lllll}
\hline $\begin{array}{l}\text { Cost and return } \\
\text { Components }\end{array}$ & Unit & Reduced & Minimum & Maximum \\
\hline Yield & & & & \\
Sale price & $\mathrm{kgha}^{-1}$ & 9760.00 & 12670.00 & 12990.00 \\
Total cost of production & $\mathrm{Nkg}^{-1}$ & 50.00 & 50.00 & 50.00 \\
\hline
\end{tabular}

\section{Conclusions}

In this study, determination of energy balance and economic analysis of cucumber production in three tillage methods have been investigated and the following points were drawn from the study:

The results shows that the maximum tillage consumed the highest total energy of $26,082.35 \mathrm{MJha}^{-1}$ with an average value of 8,694.12 $\mathrm{MJha}^{-1}$, followed by minimum tillage with a total energy value of 23,323.26 $\mathrm{MJha}^{-1}$ with an average of 7,774. $42 \mathrm{MJha}^{-1}$, while the least total energy value of 17,064.79 MJha-1 with an average value of 5,688.26 $\mathrm{MJha}^{-1}$ was expended in reduced tillage.

Averagely, minimum tillage has the highest energy ratio of 1.27 while the least value of 1.26 was estimated in reduced tillage; reduced tillage has energy productivity value of $1.57 \mathrm{MJkg}^{-1}$, while the least energy productivity 
of $1.47 \mathrm{MJha}^{-1}$ was estimated in maximum tillage. The highest net energy gain of $2157.84 \mathrm{MJ} / \mathrm{ha}^{-1}$ was analyzed in minimum tillage, followed by reduced tillage with a value of $1520.40 \mathrm{MJha}^{-1}$, while the least energy gain with a value of $1409.60 \mathrm{MJha}^{-1}$ was calculated in maximum tillage.

The highest benefit-cost ratio of 2.94 was found in minimum tillage, followed by maximum tillage with a value of 2.35 , while least value of 2.08 was estimated in reduced tillage.

The highest mean net return of $\$ 418,500.00 \mathrm{k}$ was realized in minimum tillage, followed by maximum tillage with a sum of $\$ 373,500.00 \mathrm{k}$, while the least sum of $\$ 253,250.00 \mathrm{k}$ was estimated in reduced tillage respectively.

\section{References}

1. Abdussalam, O. Y. (2015). Modelling of Energy Requirement Demand for Tillage Operations in Maize Production. An Unpublished ph.D Thesis submitted to the Department of Agricultural Engineering Ahmadu Bello University, Zaria, Nigeria.

2. Ashraf, M. N., Mahmood, M. H., Sultan, M., Shamshiri, R. R. and Ibrahim, S. M. (2021). Investigation of Energy Consumption and Associated CO2 Emissions for Wheat-Rice Crop Rotation Farming. Energies, Vol. 14: $1-18$.

3. Askhan, N.P., Reza, A., and Shahin, R. (2014). Investigation of Energy Consumption for Rice Production Using Artificial Neural Networks in Guilan Province, Iran. Journal of Elixir Enerhyand Environment, 70 : 24103-24106.

4. Bertocco, M., Basso, B., Sartori, L., and Martin, E. C. (2008). Evaluating Energy Efficiency of Site-Specific Tillage in Maize in NE Italy. Bio-Resource Technology, 99(15): 6957-6965.

5. Erdal, G., Esengun, K., Guduz, O. (2007). Energy Use and Economic Analysis of Sugar Beet Production in Tokat Province of Turkey. Energy, 32: 34-41.

6. Fadavi, R., keyhani, A., and Mohataseri, S. S. (2011). An Analysis of Energy Use, Input costs and Relation between Energy Inputs and Yield of Apple Orchard. Research on Agricultural engineering, 57(3): 88 - 96.

7. Isaac, B. A. and Babajide, S. K. (2015). Energy Input in the Production of Cassava. Journal of Energy and Environment Research, 5(1): $42-48$.

8. Khan, M. A., Awan, I. U. and Zafar, J. (2009). Energy Requirement and Economic Analysis of Rice Production in Western Part of Pakistan. Soil and Environment, 28(1): 60-67.

9. Kizilaslan, H. (2009). Input - Output Energy Analysis of Cherries Production in Tokat Province of Turkey, Applied Energy, 86: 1354-1358.

10. Majid, R., Mohammad, G. and Saeed, A. (2011). Effect of Different Tillage Methods on Yield and Yield Components of Tomato (lycopersicon esculentum), Journal of Agricultural and Biological Science, 5(2): $26-30$.

11. Morteza, T., Hassan, G. M. and Nasim, M. (2012). Energy input-output modeling and economical analyze for corn grain production in Iran. Journal of Elixir Agriculture, 52: 11500 - 11505.

12. Omid, M. A., Baharlooei, S. and Ahmadi, H. (2011). Modeling Drying Kinetics of Pistachio Nuts with Multilayer Feed-Forward Neural Network. Drying Technology, 27(10): 1069 - 1077.

13. Pishgar Komleh, S. H., Keyhani, A., Rafiee, S. H. and Sefeedpary, P. (2011). Energy use and Economic Analysis of Corn Silage Production under Three Cultivated Area Levels in Tehran Province of Iran. Energy, 36(5): 3335-3341.

14. Tabatabaeefar, A., Emamzadeh, H., GhasemiVarnam-khasti, M., Rahimizadeh R., Karimi, M. (2009). Comparison of Energy of Tillage Systems in Wheat Production. Energy, 34: 41-45.

15. Yadav, R. S. and Khandelwal, N. K. (2013). Effect of Various Energy Inputs on Energy Requirement for Wheat Production in Agro-climatic Region (Kamore plateau and Satpura Hill), M.P. India. International Journal of Engineering Research and Applications (IJERA), 3(3):531-536

16. Yildiz, T. (2016). An Input-Output Energy Analysis of Wheat Production in Çarşamba District of Samsun Province. Journal of Agricultural Faculty of Gaziosmanpasa University, 33(3), 10-20 